\title{
Estimating Evapotranspiration and Its Components in Cotton Fields under Deficit Irrigation Conditions
}

\author{
Na Wu ${ }^{1,2}$, Chuanjie Yang 3 , Yi Luo ${ }^{1,2,3 *}$, Lin $\mathrm{Sun}^{3}$ \\ ${ }^{1}$ State Key Laboratory of Desert and Oasis Ecology, Xinjiang Institute of Ecology and Geography, \\ Chinese Academy of Sciences, Urumqi, China \\ ${ }^{2}$ University of Chinese Academy of Sciences, Beijing, China \\ ${ }^{3}$ Key Laboratory of Ecosystem Network Observation and Modeling, Institute of Geographic Sciences \\ and Natural Resources Research, Chinese Academy of Sciences, Beijing, China
}

Received: 22 September 2017

Accepted: 29 November 2017

\begin{abstract}
Estimating field crop evapotranspiration $\left(E T_{c}\right)$ along with its components of soil evaporation and crop transpiration is crucial for developing effective agricultural water-saving strategies. This study separately estimated $E T_{c}$ and its components in cotton fields using a SIMDualKc dual crop coefficient model. Data from a 2-year experiment (2010-2011) were used for model calibration and validation analysis. The experimental plots were irrigated at $1.00,0.85,0.70,0.55$, and 0.45 of full irrigation amount in north Xinjiang, China. Based on the results, SIMDualKc accurately estimated actual evapotranspiration $\left(E T_{c a d j}\right)$ and its components under deficit drip irrigation conditions. Cotton field transpiration accounted for $85.4-94.3 \%$ of the $E T_{c}$ in the study area. Although plastic film significantly limited evaporative water loss, the fraction of water loss was still 5.7-14.6\% of irrigation water. The adopted estimation method could lead to better understanding of where and when water loss occurs and how much water should be used for maximal benefit. A better understanding of these factors is critical for sustainable agricultural water management practices.
\end{abstract}

Keywords: crop coefficient, SIMDualKc model, crop transpiration, soil evaporation

\section{Introduction}

The severity of water scarcity is worsening in arid northwestern China, where almost all the surface waters are used and more than one-half of the groundwater system is exploited to expand the development of artificial oases for crop production [1-2]. Reversing this trend

*e-mail: luoyi@igsnrr.ac.cn requires developing efficient water-saving irrigation practices for use in agricultural production in the region.

The fate of irrigation water in agricultural fields includes soil evaporation, crop transpiration and deep percolation below the root zone [2]. Among these, the beneficial pathway for crop growth and yield is transpiration. Improved and deficit irrigation management strategies could increase the proportion of water used by crops as transpiration and reduce soil water loss in the form of evaporation and deep percolation [3-5]. Mulched drip irrigation has been shown to be successful, yielding 
significant water-saving potential in agricultural fields in the Xinjiang Autonomous Region in northwestern China [6].

Understanding crop evapotranspiration $\left(E T_{c}\right)$ and its components of soil evaporation $(E)$ and crop transpiration $(T)$ is critical for optimizing agricultural water use [3]. Additionally, the accurate estimation of $E T_{c}$ and its components is vital for efficient water management and irrigation scheduling. A range of methods and measurements has been used to estimate crop water use and water-saving potential [7] and to enhance irrigation scheduling for optimal crop production [8-9].

Data on actual evapotranspiration $\left(E T_{c \text { act }}\right)$ may be derived from a range of measurement systems [10-11], including lysimeters [12-13], eddy covariance [6-7, 11], the Bowen ratio [14-16], water budget analysis [7, 11], sap flow analysis [17], satellite-based remote sensing [18], and model simulations [19]. Of these systems, the FAO-56 dual crop coefficient approach is considered the most accurate for estimating daily $E T_{c}$, as it separately calculates soil evaporation and crop transpiration [20-22].

The dual crop coefficient approach allows for accurate estimation of the water-saving potential of a water management strategy from the ratios of evaporation to reference evapotranspiration $(E / E T)$, and transpiration to reference evapotranspiration $\left(T / E T_{0}\right)$. Additionally, the dual crop coefficient approach allows for more accurate planning of irrigation scheduling, especially under partial crop cover or drip irrigation conditions [20-22]. Another advantage of the dual crop coefficient approach is that it more precisely simulates the effects of mulching on soil evaporation.

SIMDualKc is a model that simulates irrigation scheduling (amounts and timing) and thus $E T_{c}$ using the dual crop coefficient approach in a soil-water balance environment [20-21]. SIMDualKc has been successfully calibrated and validated for a variety of crops under different weather and irrigation scenarios [23-25], and has been applied in particular to maize and wheat [26-29]. SIMDualKc can be used to simulate drip systems by inputting the fraction of wet soil due to irrigation. This model can also be used to simulate the effects of mulching on soil evaporation.

Cotton is suitable for cultivation under limited irrigation water conditions, and it has been extensively tested on research and commercial farms across the globe $[8,22]$. In arid Xinjiang in northwestern China, cotton is the main cash crop cultivated on more than one-third of the total agricultural land in the region [30]. The area planted with cotton is rapidly expanding due to the introduction of drip irrigation in the region. Although SIMDualKc has been successfully applied to simulate the soil-water balance with $E T_{c}$ computed with the dual $K_{c}$ in central Asia [21], such simulations are rare in China. Thus, the main objective of this study is to test the performance of SIMDualKc in estimating $E T_{c}$ under plastic mulching with several drip irrigation strategies. Also using SIMDualKc, this study partitioned $E T$ into its components of crop transpiration and soil evaporation with the dual $K_{c}$. And we analyzed the dual $K_{c}$ along with the related driving factors under different cotton management scenarios - especially under deficit irrigation conditions.

\section{Materials and Methods}

\section{Study Site}

Field experiments were set up in the Irrigation Experimental Station $\left(85^{\circ} 59^{\prime} \mathrm{E}, 4^{\circ} 19^{\prime} \mathrm{N}\right)$ of Shihezi University, Xinjiang, China, in the 2010 and 2011 cotton growing seasons. The station is located in the middle reach of the Manas River Oasis, which is in a warm-temperate continental climate zone. Meteorological data were obtained from Shihezi Station, which is a long-term monitoring station located in a temperate continental climate zone. Based on 30a (1976-2006) meteorological data, the average annual sunshine in the region is $2,861 \mathrm{~h}$, and the frost-free growing season is 170 days. The annual mean temperature is $7^{\circ} \mathrm{C}$, and the mean maximum and minimum temperatures are $25.4^{\circ} \mathrm{C}$ and $-15^{\circ} \mathrm{C}$, respectively. The relative humidity during the summer months is $30-50 \%$, whereas the annual precipitation and pan evaporation are $210 \mathrm{~mm}$ and $1,664 \mathrm{~mm}$, respectively. Reference evapotranspiration $\left(E T_{o}\right)$ is calculated based on the Peman-Monteith equation (as suggested by the FAO-56), using the observations from an automatic weather station within the experimental field.

The experimental plots were set up in 2010 in a local cotton field under continuous rotation for approximately 10 years. In the oasis region of Xinjiang, continuous cotton cropping has been the most common agronomy practice over the last 50 years. To lighten the pressure of continuous cropping, other local farm practices, such as pre-winter deep tillage, selection of disease/insectresistant cotton varieties, and pre-sowing fungicide dressing are normally done.

\section{Planting}

In this study, the cotton Xinluzao 7 (Gossypium hirsutum L.) was sown in early May 2010 and late April 2011, and both were harvested in mid-September. The experiment adopted a double-line design, which is most appropriate for drip irrigation scheduling and agronomic practices in cotton fields in Xinjiang [31]. As shown in Fig. 1, two drip lines were placed between the two outer cotton rows with alternating row spacing of $30 \mathrm{~cm}$ and $50 \mathrm{~cm}$. Along the rows, the cotton seeds were planted at $12 \mathrm{~cm}$ intervals to yield a planting density of 222,000 plants $\mathrm{ha}^{-1}$. The land surface was approximately $72 \%$ mulched, with 0.08 mm-thick plastic film at planting.

Each treatment was replicated 3 times on equal plots with dimensions of $5.4 \times 20 \mathrm{~m}$. Also, each main plot consisted of three $1.3 \times 20 \mathrm{~m}$ bed replicates used 


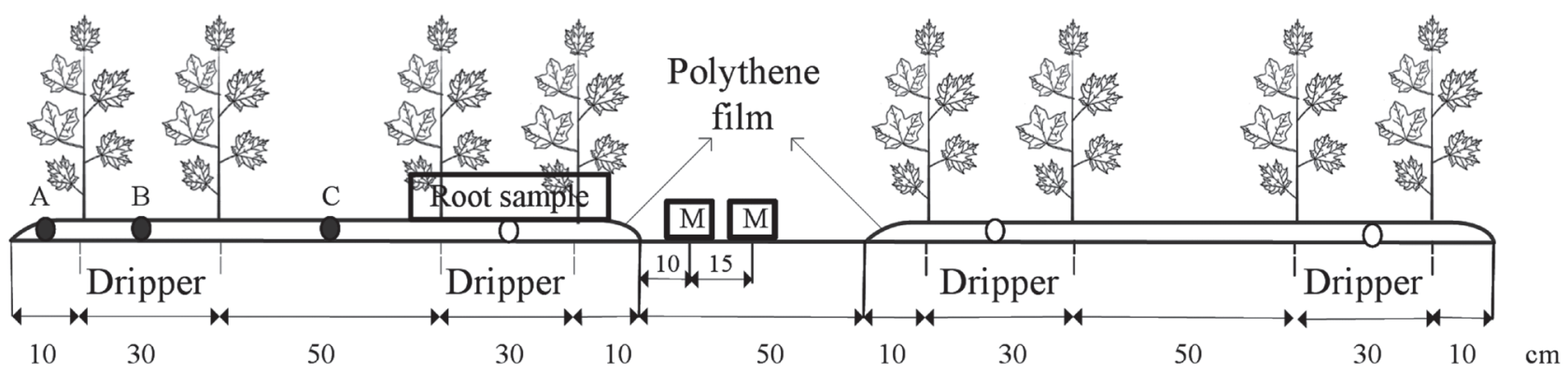

Fig. 1. Layout of the planting pattern and drip lines and the positions of soil sample collection points; soil water content was measured at points $\mathrm{A}, \mathrm{B}$, and $\mathrm{C}$, and the micro-lysimeters were located at the points labeled $\mathrm{M}$.

to prevent potential border effects on sampling. For the 3 replicate beds per plot, one was used for collecting plant and root samples, another for collecting soil moisture data, and the third for cotton yield.

Each bed was planted in 4 rows and lined with 2 irrigation drips. The experimental plots (each $5.4 \times 20 \mathrm{~m}$ ) were planted, irrigated, and fertilized in accordance with local cotton cultivation practices in the region to ensure that germination and seedling establishment occurred during the early growth stage.

\section{Irrigation Plot-Test Design}

The irrigation schedules in the 2a experimental period are shown in Table 1. Five treatments were used in the experiment (full irrigation at $\mathrm{T} 1$ and deficit irrigations at T2, T3, T4, and T5). Irrigation was applied via surface dripping and irrigation dates based on local farming practices in the study area. All three replicates of the treatments had a completely randomized block design. The simulations were driven by the irrigation depths and dates in the field experiments. Irrigation was performed roughly once a week starting in mid-June and ending in late August for both years. The irrigation lasts for about $10 \mathrm{~h}$ for each irrigation event and the flow is about 15 $\mathrm{m}^{3} \mathrm{~h}^{-1}$ with the meter measurement. The irrigation tape is made of plastic and the external diameter of the irrigation tape is $16 \mathrm{~mm}$, the wall thickness is about $0.2 \mathrm{~mm}$, the space between the drip holes is about $0.3 \mathrm{~m}$, the work pressure is $0.10 \mathrm{MPa}$, and the flow rate of each tape is $1.6 \mathrm{~L} \mathrm{~h}^{-1}$.

\section{Sampling and Measurements}

In each replicate plot, 10 plants were flagged for measuring crop height at different growth stages. Another 3 plants were selected for leaf area $(L A)$ measurement, from which the leaf area index (LAI) was derived by dividing the unit ground surface area. The leaves were excised, and $L A$ was determined using an automatic area meter (AMM-7, Hayashideno Inc., Tokyo, Japan). The meter was calibrated on actual $L A$ derived from digital image processing of data from preliminary experiments involving 10 plants. Leaves of a whole plant were individually laid on a piece of paper $(42 \times 29.7 \mathrm{~cm})$ and scanned, and then $L A$ was calculated in a geographic information system (GIS) environment after converting the scanned images into a BMP file using Photoshop.

Two parallel root samples (Fig. 1) were taken in the vertical direction of the drip line for each replicate, and this was repeated 3 times in the growing season in 2011 using a $10 \mathrm{~cm}$-diameter soil column cylinder auger (Royal Eijkelkamp Earth Sampling Group, Netherlands) powered by an electrically driven hammer (Makita Inc. USA). The first sampling event was on 10 June (rapid growth stage) and was conducted in only one bed due to the highly uniform cotton growth before the application of different irrigation events. The others were conducted in the first replicate bed of each treatment: on 27 July (mid-season stage) and 20 August (senescence/ maturity).

Root depth was determined by measuring the length of the tap root. Soil cores were taken below the plant

Table 1. Irrigation amount (mm) for different treatments for cotton in 2010-2011.

\begin{tabular}{|c|c|c|c|c|c|c|c|c|c|c|}
\hline \multirow{2}{*}{ Growth Stage } & \multicolumn{2}{|c|}{$\mathrm{T} 1(\mathrm{~mm})$} & \multicolumn{2}{|c|}{$\mathrm{T} 2(\mathrm{~mm})$} & \multicolumn{2}{|c|}{$\mathrm{T} 3(\mathrm{~mm})$} & \multicolumn{2}{|c|}{$\mathrm{T} 4(\mathrm{~mm})$} & \multicolumn{2}{|c|}{$\mathrm{T} 5(\mathrm{~mm})$} \\
\hline & 2010 & 2011 & 2010 & 2011 & 2010 & 2011 & 2010 & 2011 & 2010 & 2011 \\
\hline Initial stage (0-25 d) & 36 & 36 & 36 & 36 & 36 & 36 & 36 & 36 & 36 & 36 \\
\hline Development stage (26-70 d) & 180 & 180 & 153 & 153 & 126 & 126 & 99 & 99 & 81 & 81 \\
\hline Boll development stage (71-120 d) & 240 & 240 & 204 & 204 & 168 & 168 & 132 & 132 & 108 & 108 \\
\hline Maturity stage (>120 d) & 69 & 34 & 59 & 29 & 48 & 24 & 38 & 19 & 31 & 15 \\
\hline Whole developing stage & 525 & 490 & 452 & 422 & 378 & 354 & 305 & 286 & 256 & 240 \\
\hline
\end{tabular}


column at depths of $40 \mathrm{~cm}, 70 \mathrm{~cm}$, and $100 \mathrm{~cm}$ in the 3 sampling events, and the soil cores were partitioned into $10 \mathrm{~cm}$ sub-samples. The samples were then taken to the laboratory, and roots were manually collected after removing soil by rinsing in washing cans with dimensions of $25 \times 50 \mathrm{~cm}$. The collected roots were carefully spread out on paper and photographed. Then the root length was determined using ARC/INFO image analysis, as proposed by Zheng et al. [32]. The suggested root depth at the planting/initiation stage is $28 \mathrm{~cm}$ [33]. The root depth during the end season/harvest stage was equal to the depth measured during the senescence/maturity stage as roots reached maximum size at cotton maturity.

The water content of the soil layer was measured using a CPN 503DR neutron probe (CPN International Inc.). Three access tubes were installed in the middle of plastic films consisting of narrow and wide rows (Fig. 1). Measurements were performed at $10 \mathrm{~cm}$ intervals down to $120 \mathrm{~cm}$ below the land surface. The neutron probe was calibrated for each soil depth with soil water data under field conditions. Soil water content was measured 4 times by gravimetric soil water methods during the cotton growth season and at the same depth and same time as the neutron probe. The soil samples were taken to the laboratory and oven-dried at $105^{\circ} \mathrm{C}$ for $24 \mathrm{~h}$ until a stable weight was attained. A total of 40 points data were used in a linear regression analysis, and the results suggest that the neutron probe adequately measured soil-water content at $30-120 \mathrm{~cm}$ soil depth $\left(R^{2}, 0.70-0.80\right)$. For the top $20 \mathrm{~cm}$ soil layer (where soil water was underestimated), soil samples were collected and gravimetrically analyzed for soil water content using the soil bulk density factor in Table 1. Soil water content measurements were taken before and after every irrigation or precipitation event in the region. The available soil water in the maximum root depth in the root-zone soil layer $\left(A S W_{r m}\right)$ was calculated as the difference between soil water content and permanent wilting point of the soil layer:

$$
A S W_{r m}=1000 \mathrm{~g}\left(\theta-\theta_{w p}\right) \mathrm{g} Z_{r}
$$

...where $\theta$ is water content in the soil layer $\left(\mathrm{m}^{3} \mathrm{~m}^{-3}\right), \theta_{w p}$ is water content at wilting point $\left(\mathrm{m}^{3} \mathrm{~m}^{-3}\right)$, and $Z_{r}$ is the maximum root depth (m).

Due to lack of a lysimeter, $E T_{c \text { act }}$ was determined from soil water budget analysis, which is most accurate in crop fields with limited irrigation, as is the case in this study [34]. Here, $E T_{\text {c act }}$ was determined for the periods between successive irrigation events as follows:

$$
E T_{\text {cact }}=I+P+\Delta S-R-D
$$

...where $I$ is irrigation amount, $P$ is precipitation, $\Delta \mathrm{S}$ is change in soil water storage, $R$ is surface runoff, and $D$ is drainage below root zone (all variables in $\mathrm{mm}$ ). In this study, $I$ and $D$ were considered negligible because of the arid climate and deficit irrigation conditions. As more than $95 \%$ of root water extraction occurred in the soil profile above the $120 \mathrm{~cm}$ soil depth, $E T_{\text {c act }}$ in the region was calculated from Equation (2) using data for the $0-120 \mathrm{~cm}$ soil profile [34].

Soil evaporation in the cotton field was determined using 2 micro-lysimeters placed between the two rows of crops (Fig. 1) in each plot replicate [35]. The hammerdriven micro-lysimeter consisted of iron sheets $(2 \mathrm{~kg}$ in weight), an outer cylinder (11 cm in diameter) with a bottom lid, an internal cylinder (10 $\mathrm{cm}$ in diameter) without a bottom lid, and walls $7 \mathrm{~mm}$ thick and $10 \mathrm{~cm}$ deep. For each measurement, the micro-lysimeters were removed from the soil, sealing the bottom with a plastic cap, weighed at 09:00, and reinstalled in the same place. This was performed every 2-4 d, and the measurements for 2 successive days were used to calculate the evaporation from the lysimeter soil mass. The microlysimeter soil mass was replaced every 4-6 d or after every precipitation and irrigation event so that the soil moisture of the lysimeter soil mass was consistent with the field conditions.

The following section is divided by subheadings and should provide a concise and precise description of the experimental results, their interpretation, and the experimental conclusions that can be drawn.

\section{Statistical Analyses}

Statistical analyses (ANOVA and regression analyses) were performed in the SPASS 19.0 software environment. The mean values were processed using Duncan's multiple range tests for one-way ANOVA analysis at $P<0.05$.

\section{Evapotranspiration Calculations}

Details of the standard processes of the dual crop coefficient approach in SIMDualKc are documented by Allen et al. [7] and Rosa et al. [20]. This study only describes relevant basic equations of the model for clarity.

\section{Dual Crop Coefficient Approach}

For water-scarce conditions, crop evapotranspiration is estimated as follows [7, 20]:

$$
E T_{c a d j}=\left(K_{s} K_{c b}+K_{e}\right) E T_{o}
$$

...where $E T_{\text {cadj }}$ is the simulated crop evapotranspiration and $\mathrm{ET}_{\mathrm{o}}$ is the reference evapotranspiration ( $\mathrm{mm} \mathrm{d}^{-1}$, calculated using the FAO P-M equation [20]); $K_{c b}$ is the basal crop coefficient, defined as $E T_{c} / E T_{o}$ under a dry surface soil layer but with adequate root-zone soil water to sustain full plant transpiration; $K_{\mathrm{e}}$ is the soil evaporation coefficient, describing evaporation from soil surface; and $K_{s}$ is the water stress coefficient, describing the effect of water stress on crop transpiration. 


\section{Basal Crop Coefficient}

In FAO-56, the basal crop coefficient $\left(K_{c b}\right)$ curve is divided into 4 growth stages: initial, development, midseason, and late-season. Three point-values of $K_{c b}\left(K_{c b \text { ini' }}\right.$, $K_{c b \text { mid }}$, and $K_{c b \text { end }}$ ) are required to generate a $K_{c b}^{c b}$ curve $[7,36]$. The recommended values of $K_{c b}$ are listed in the literature [7] for a sub-humid climate with a minimum relative humidity $\left(R H_{\min }\right)$ of $45 \%$ and a moderate wind speed of $2 \mathrm{~m} \mathrm{~s}^{-1}$. Adjustments for climatic conditions with $\mathrm{RH}_{\min }$ values different than $45 \%$ or wind speeds different than $2 \mathrm{~m} \mathrm{~s}^{-1}, K_{c b \text { mid }}$ and $K_{c b \text { end }}$ values exceeding 0.45 should be calculated as follows:

$$
K_{c b}=K_{c b(T a b)}+\left[0.04\left(\mu_{2}-2\right)-0.004\left(R H_{\min }-45\right)\right](h / 3)^{0.3}
$$

...where $\mathrm{K}_{\mathrm{cb}(\mathrm{Tab})}$ is the value of $\mathrm{K}_{\mathrm{cb}}$ for a wind speed of $2 \mathrm{~m} \mathrm{~s}^{-1}$ and an $\mathrm{RH}_{\min }$ of $45 \%, \mu_{2}$ and $\mathrm{RH}_{\min }$ are the average observed values during the mid/late-season stage, and $h$ is average crop height during the mid/lateseason stage.

\section{Soil Evaporation Coefficient}

The soil evaporation coefficient $\left(K_{e}\right)$ is calculated in a daily-time-step using the soil water balance approach for evaporation (surface) of the soil layer $\left(Z_{e}\right)$ as in Equation (71) of FAO-56 paper:

$$
K_{e}=K_{r}\left(K_{c \max }-K_{c b}\right) \leq f_{e w} K_{c \max }
$$

...where $K_{r}$ is a dimensionless evaporation coefficient dependent on the cumulative depth of depleted water from the topsoil, $K_{c \max }$ is the maximum $K_{c}$ after a rain or irrigation event, and $f_{e w}$ is the fraction of soil that is both exposed and wetted. Detailed equations for calculating $K_{c \max }, K_{r}$, and $f_{e w}$ are given by [20].

\section{Stress Coefficient}

The soil water stress coefficient $(K)$ is expressed as a linear function of root-zone soil water depletion that is in excess of readily available water in the effective root zone:

$$
\begin{gathered}
K_{s}=\left(T A W-D_{r}\right) /(T A W-R A W)=\left(T A W-D_{r}\right) \\
/(1-p) T A W \text { for } D_{r} \leq R A W
\end{gathered}
$$

$$
K_{s}=1 \quad \text { for } \quad D_{r} \leq R A W
$$

... where $T A W$ and $R A W$ are the total and readily available soil water $(\mathrm{mm}), p$ is the depletion fraction at stress initiation, and $D_{r}$ is the root zone depletion (mm).

$$
T A W=1000\left(\theta_{F C}-\theta_{W P}\right) Z_{r}
$$

...where $\theta_{F C}$ and $\theta_{W P}$ are the soil water contents at field capacity and wilting point, respectively $\left(\mathrm{m}^{3} \mathrm{~m}^{-3}\right)$, and $Z_{r}$ is the root depth.

$$
R A W=p T A W
$$

... where the terms are defined as above.

$$
D_{r, i}=D_{r, i}-1-P_{i}-I_{i}+E T_{c, i}
$$

...where $D_{r, i}$ is the root zone depletion at the end of day $i(\mathrm{~mm}), D_{r, i-1}$ is the root-zone water content at the end of the previous day $i-1(\mathrm{~mm}), P_{i}$ is the precipitation on day $i(\mathrm{~mm}), I_{i}$ is the net irrigation depth on day $i(\mathrm{~mm})$, and $E T_{c, i}$ is the crop $E T$ on day $i(\mathrm{~mm})$.

\section{Surface Mulching}

Mulching influences soil evaporation by reducing the amount of energy available at the soil surface, increasing albedo and insulating the soil surface from radiation and convective heat transfer. These effects are simulated by changing the fraction of soil surface $(f)$ shaded or otherwise shielded from solar radiation [37]. Under plastic mulch, these effects are simulated in SIMDualKc by tying $K_{e}$ to vent hole area plus the area between plastic sheets or crop rows (the larger of the two) wetted by irrigation or precipitation, respectively. Under plastic mulch, evaporation is null, except for that escaping through vent holes. Thus, the applied mulch adjustment for $K_{e}$ in SIMDualKc is the fraction of the soil surface corresponding to vent holes, which depends on the number of crop rows per plastic sheet, row spacing, hole spacing along row, and hole diameter [20].

\section{Data Input}

Under deficit drip irrigation, surface run-off and deep percolation below $100 \mathrm{~cm}$ soil depth were assumed to be negligible. Thus, the data used to drive the SIMDualKc model are summarized in the successive paragraphs below.

The meteorological daily data included minimum and maximum air temperatures $\left(T_{\min }\right.$ and $\left.T_{\max },{ }^{\circ} \mathrm{C}\right)$, reference crop evapotranspiration $(E T, \mathrm{~mm})$, minimum and average relative humidity values $\left(R H_{\text {min }}\right.$ and $R H_{\text {mean }}$, $\%$ ), precipitation $(\mathrm{P}, \mathrm{mm})$, and wind speed at $2 \mathrm{~m}$ height $\left(\mu_{2}, \mathrm{~m} \mathrm{~s}^{-1}\right)$.

The soil data included soil layer depth (m), field capacity and wilting point soil water contents $\left(\theta_{F C}\right.$ and $\left.\theta_{W P}, \%\right)$, effective evaporation layer depth $\left(Z_{e}, \mathrm{~m}\right)$, the total available water $\left(T A W, \mathrm{~mm} \mathrm{~m}^{-1}\right)$ and readily and total evaporable water (REW and TEW, $\mathrm{mm}$ ), and soil texture.

The crop data included initial, development, mid-season, late-season (senescence/ maturity), and 
harvest/end-season dates; tabulated/observed basal crop coefficients $\left(K_{c b}\right)$ for the initial, mid-season, and end-season stages; minimum crop coefficient for bare soil $\left(K_{c \text { min }}\right)$; root depth $\left(Z_{r}, \mathrm{~m}\right)$, plant height $(h, \mathrm{~m})$, non-stress soil water depletion fraction $(p)$, and ground cover fraction $(C C)$ [38]; multiplier factor $(M L)$; and row orientation and width.

The irrigation data included irrigation system, irrigation wetted soil fraction $\left(f_{w}\right)$, and irrigation scheme (dates and depth).

The mulching data included the plastic film-covered soil fraction, crop rows per plastic sheet, hole spacing along rows, and hole diameter.

\section{Model Calibration and Validation}

The SIMDualKc model was first calibrated and validated for relevant parameters before being used to estimate $E T$ and its components under deficit irrigation in cotton field. The model calibration included adjusting model-simulated standard crop $\left(K_{c b}\right.$ and $\left.p\right)$, soil $\left(Z_{e}, T E W\right.$ and $R E W$ ), and initial soil water content agree with the observed soil water content, soil evaporation and $E T_{c}$ in 2010. The model validation included using the calibrated parameters to simulate the experimental values in 2011 .
Both qualitative and statistical analyses were used to evaluate the goodness of fit of the SIMDualKc model predictions and observations, and the results represented in graphs and linear regressions. The goodness of fit for soil water content included the regression coefficient (b), coefficient of determination $\left(R^{2}\right)$, root mean square error (RMSE), average absolute error $(A A E)$, index of agreement $\left(d_{I A}\right)$, and modeling efficiency $(E F)$ as described with more details by Rosa et al. [21].

\section{Results and Discussion}

\section{Calibration and Validation Results}

The parameters used in this study to determine $E T_{c}$ in the cotton field are listed in Table 2. Under water deficit conditions, $K_{c b}$ and $p$ were adjusted to the local climatic and soil water stress conditions. For all of the management scenarios, the model was calibrated by varying $K_{c b i n i}, K_{c b \text { mid }}, K_{c d \text { end }}$ and $p$ to match the simulated available soil water $(A S W)$ as closely as possible to the observed $A S W$. The $K_{c b \text { ini }}$ and $p$ and the calibrated values under various water-deficit conditions are summarized in Table 3. For non-water deficit (T1) or

Table 2. Main parameters used to determine evapotranspiration in cotton fields; $\uparrow$ denotes that the last irrigation (50 mm) was canceled in 2011 due to heavy rains (approximately $40 \mathrm{~mm}$ ) in late August.

\begin{tabular}{|c|c|}
\hline Parameter & Value \\
\hline Effective depth of evaporation layer $\left(Z_{\mathrm{e}}, \mathrm{m}\right)$ & 0.1 \\
\hline Total evaporable water $(T E W, \mathrm{~mm})$ & 27 \\
\hline Readily evaporable water $(R E W, \mathrm{~mm})$ & 8 \\
\hline Wetted fraction $(f w)$ & 0.4 \\
\hline Plastic film-covered soil fraction & 0.72 \\
\hline Crop rows per plastic sheet & 4 \\
\hline Row width $(\mathrm{m})$ & 0.4 \\
\hline Row orientation & North-South \\
\hline Hole spacing along row (m) & 0.12 \\
\hline Hole diameter $(\mathrm{m})$ & 0.05 \\
\hline Initial evaporable layer depletion $(T E W, \%)$ & $0(2010) / 30 \%(2011)$ \\
\hline Initial depletion of layer below $(T E W, \%)$ & $0(2010) / 0(2011)$ \\
\hline Multiplier factor $(M L)$ & 2.0 \\
\hline Planting/Initiation & 5 May 2010 / 25 April 2011 \\
\hline Rapid growth start & 31 May 2010 / 21 May 2011 \\
\hline Mid-season start & 7 July 2010 / 28 June 2011 \\
\hline Senescence/maturity start & 23 August 2010 / 18 August 2011 \\
\hline End-season/harvest & 29 September 2010 / 19 September 2011 \\
\hline Cumulative pan evaporation & $1,102 \mathrm{~mm}(2010) / 1,113 \mathrm{~mm}(2011)$ \\
\hline Seasonal irrigation at full irrigation amount (T1) & $525 \mathrm{~mm}(2010) / 490 \mathrm{~mm}(2011) \dagger$ \\
\hline
\end{tabular}


Table 3. Standard and calibrated values of basal crop coefficient $\left(K_{c b}\right)$ and depletion fraction $(p)$ of cotton under different water deficit conditions.

\begin{tabular}{|c|c|c|c|c|c|c|c|}
\hline & \multirow{2}{*}{ Growth stage } & \multirow{2}{*}{ Standard } & \multicolumn{5}{|c|}{ Calibrated } \\
\hline & & & $\mathrm{T} 1$ & $\mathrm{~T} 2$ & $\mathrm{~T} 3$ & $\mathrm{~T} 4$ & T5 \\
\hline \multirow{3}{*}{$K_{c b}$} & $K_{c b i n i}$ & 0.15 & 0.34 & 0.34 & 0.25 & 0.20 & 0.15 \\
\hline & $K_{c b \text { mid }}$ & 1.15 & 1.15 & 1.15 & 1.00 & 0.90 & 0.85 \\
\hline & $K_{c b \text { end }}$ & 0.50 & 0.40 & 0.40 & 0.40 & 0.35 & 0.30 \\
\hline \multirow{5}{*}{$p$} & Initiation & 0.65 & 0.64 & 0.64 & 0.51 & 0.40 & 0.30 \\
\hline & Rapid growth & 0.65 & 0.64 & 0.64 & 0.51 & 0.40 & 0.30 \\
\hline & Mid-season & 0.65 & 0.64 & 0.64 & 0.51 & 0.40 & 0.30 \\
\hline & Maturity & 0.65 & 0.50 & 0.50 & 0.40 & 0.33 & 0.20 \\
\hline & End-season & 0.65 & 0.30 & 0.30 & 0.20 & 0.20 & 0.10 \\
\hline
\end{tabular}

slight water deficit (T2) conditions, the values for $p$ and $K_{c b \text { mid }}$ were similar to the FAO-56 recommended values [7, $21,39]$. While $K_{c b i n i}$ was greater than 0.15 because of the combined effects of evaporative demand and mulching $[30,35]$, it was less than the FAO-56 recommended value due to the effects of ET and the lack of irrigation on the soil water content during the late growth stage [30]. For the other water-deficit treatments, the values of $K_{c b}$ and $p$ decreased drastically with increasing water deficit - especially during the late growth stage (Table 3).

The observed and simulated $A S W$ values in the root zone are shown in Fig. 2. As depicted in Fig. 2, the simulated changes in $A S W$ with irrigation were in good agreement with the ET management scenarios, suggesting

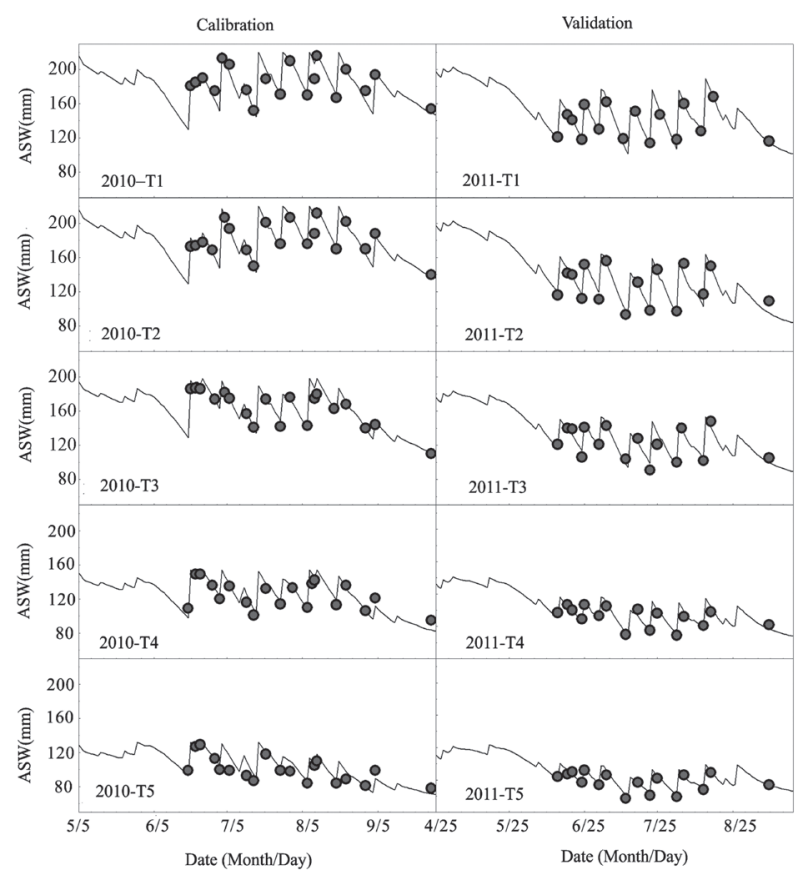

Fig.2. Comparison between field-measured and model-simulated available soil water (ASW) under different irrigation treatments in 2010 (calibration) and 2011 (validation). good model predictions for both full and deficit irrigation conditions. Table 4 also further clarifies the indicators (as goodness-of-fit) for the model calibration and validation analyses. For all the treatment cases, the regression coefficient $b$ was close to 1.0 , and $R^{2}$ was within $0.89-0.95$, suggesting that SIMDualKc accurately simulated $A S W$ for all the irrigation scheduling. Moreover, the estimation error indicators RMSE and AAE were 4.68-7.18 $\mathrm{mm}$ and 2.13-5.75 $\mathrm{mm}$, respectively. Furthermore, the modeling efficiency index $(E F)$ and the index of agreement $\left(d_{I A}\right)$ were close to 0.90 and 1.0, respectively.

The values calibrated for 2010 are plotted in Figs 3 and 4, respectively, and the validated soil evaporation and $E T_{c}$ values for 2011 are plotted in Figs 5-6. The plots in Figs 3-6 compare cumulative field-measured and modelsimulated evaporation and $E T_{c}$ for successive sampling and irrigation periods [25]. For soil evaporation, Figs 3 and 5 suggested good agreement between the observed and simulated evaporation, with respective regression coefficients $(b)$ of 1.01 and 0.95 and coefficients of determination $\left(R^{2}\right)$ of 0.94 and 0.96 . Similar to soil evaporation, the simulated and observed $E T_{c}$ (Figs 4 and 6) for the calibration and validation analyses matched well, with respective $b$ values of 0.98 and 1.04 and $R^{2}$ values of 0.83 and 0.74 . However, the model-simulated values exceeded observed values after the last irrigation event in 2011. This discrepancy between model estimates and field observations was due to the heavy rain $(40 \mathrm{~mm})$ in late August. Regardless, the results suggested that the SIMDualKc model satisfactorily predicted $A S W$ in cotton fields under different mulched drip irrigation systems in northwestern China. The model also successfully partitioned actual $E T_{c}$ into its components of soil evaporation and crop transpiration.

\section{Crop Coefficients}

Under suitable soil water conditions (T1 or T2), variations in $K_{c b}$ were minimal (Table 3), with approximate $K_{c b i n i}, K_{c b \text { mid }}$, and $K_{c b \text { end }}$ values of $0.34,1.15$, and 0.40 , 
Table 4. Goodness of fit indicators for the SIMDualKc model calibration and validation analyses.

\begin{tabular}{|c|c|c|c|c|c|c|c|}
\hline \multicolumn{2}{|c|}{ Goodness-of-fit indicator } & $b$ & $R^{2}$ & RMSE (mm) & $A A E(m m)$ & $E F$ & $d_{I A}$ \\
\hline \multirow{4}{*}{ Calibration (2010) } & $\mathrm{T} 1$ & 0.99 & 0.95 & 5.99 & 4.81 & 0.89 & 0.98 \\
\cline { 2 - 9 } & $\mathrm{T} 2$ & 0.99 & 0.90 & 6.99 & 5.75 & 0.88 & 0.97 \\
\cline { 2 - 9 } & $\mathrm{T} 3$ & 0.99 & 0.89 & 6.11 & 5.44 & 0.88 & 0.97 \\
\cline { 2 - 8 } & $\mathrm{T} 4$ & 0.99 & 0.91 & 4.68 & 3.06 & 0.89 & 0.97 \\
\cline { 2 - 9 } & $\mathrm{T} 5$ & 1.01 & 0.95 & 4.98 & 2.13 & 0.85 & 0.95 \\
\hline \multirow{3}{*}{ Validation (2011) } & $\mathrm{T} 1$ & 1.00 & 0.89 & 7.18 & 5.21 & 0.85 & 0.97 \\
\cline { 2 - 9 } & $\mathrm{T} 2$ & 1.00 & 0.91 & 7.14 & 5.73 & 0.86 & 0.97 \\
\cline { 2 - 9 } & $\mathrm{T} 3$ & 1.02 & 0.94 & 7.10 & 5.42 & 0.89 & 0.97 \\
\cline { 2 - 9 } & $\mathrm{T} 4$ & 1.01 & 0.91 & 5.52 & 6.21 & 0.84 & 0.97 \\
\cline { 2 - 8 } & $\mathrm{T} 5$ & 1.02 & 0.89 & 5.92 & 4.26 & 0.84 & 0.96 \\
\hline
\end{tabular}

respectively. While the estimated $K_{c b \text { mid }}$ and $K_{c b \text { end }}$ values were similar to those reported by Allen in 2000 under full irrigation conditions in the Gediz Valley in Turkey [36], the estimated $K_{c b i n i}$ value was higher than those reported by Allen [36], Hunsaker et al. [40], Howell et al. [39], and Rosa et al. [20]. This suggested that $K_{c b}$ is highly sensitive to local variations in climate, soil, and irrigation scheduling [41].

The variations in the dual crop coefficient $\left(K_{c}=K_{s} K_{c b}+K_{e}\right)$ curves under different soil water conditions are depicted in Fig.7. The crop coefficient varied substantially with soil water conditions, with high water content corresponding to high $K_{c}$ value. The range of the estimated $K_{c}$ for the growing season was $0.24-1.25$ under treatments $\mathrm{T} 1$ and $\mathrm{T} 2$ in 2010 and 2011. These treatments involved suitable soil water conditions, and the estimated values were similar to those noted by Ko
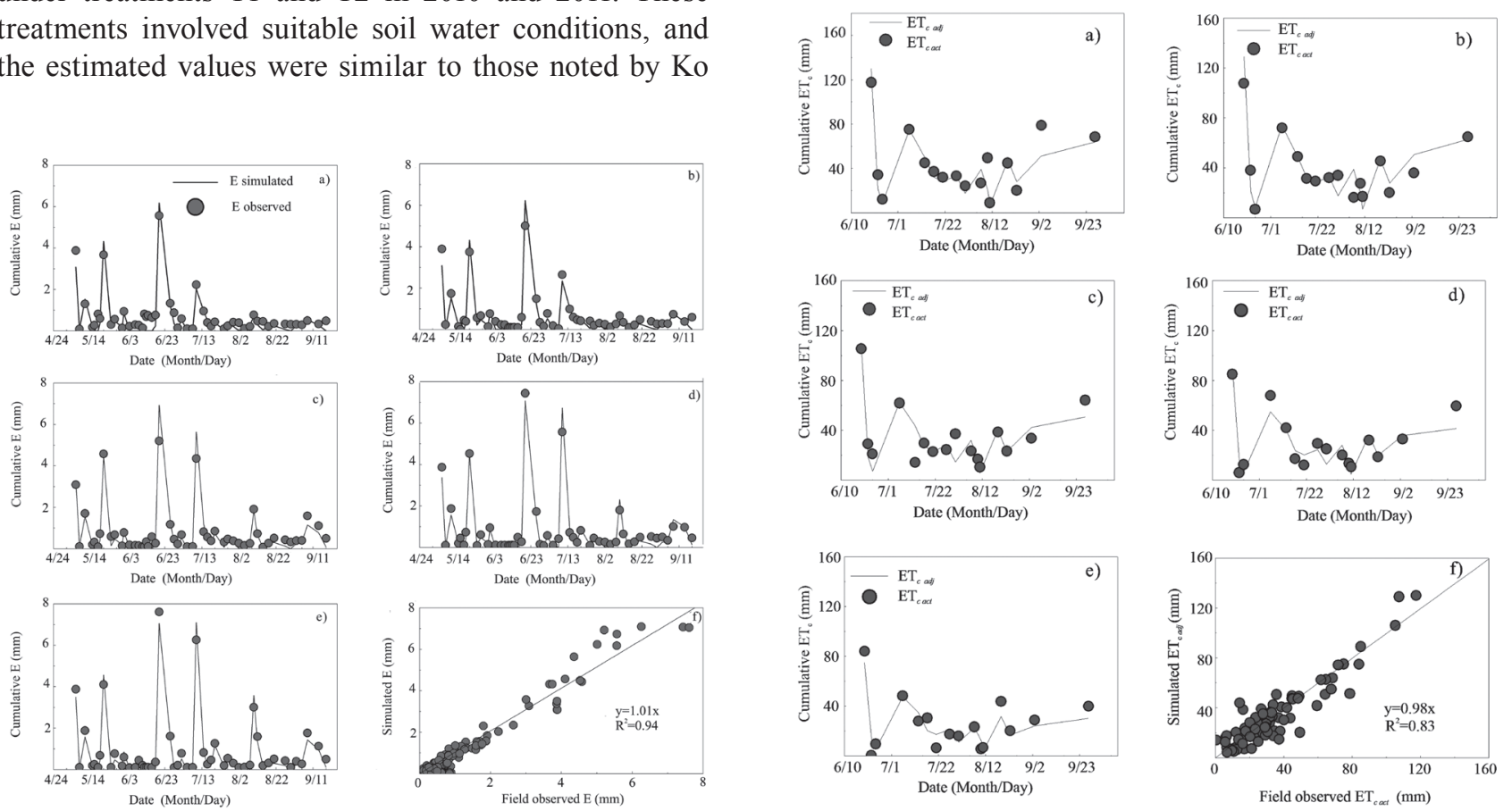

Fig. 4. Comparison between field-measured and model-simulated cumulative crop evapotranspiration $\left(E T_{c \text { adj }}\right)$ under treatments T1a), T2b), T3c), T4d), and T5e) in 2010 (calibration).
Fig. 3. Comparison between field-measured and model-simulated cumulative soil evaporation $(E)$ under different treatments in 2010 (calibration). et al. [42] in cotton fields in Uvalde, Texas $\left(K_{c}=0.2-1.5\right)$.

The estimated $K_{c}$ decreased with increasing soil water deficit were in good agreement with the findings in a humid climate. In 2011 the treatments T3, T4, and T5 featured significant variations in $K$ from early July to August. This was attributed to the dynamic changes increasing soil water stress with time after irrigation. Compared with Farahani et al. [41], the estimated $K_{c}$ was lower at the end of the growing season. This was attributed to low transpiration and evaporation driven
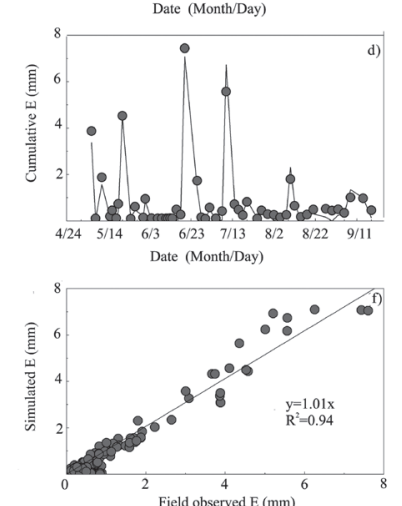

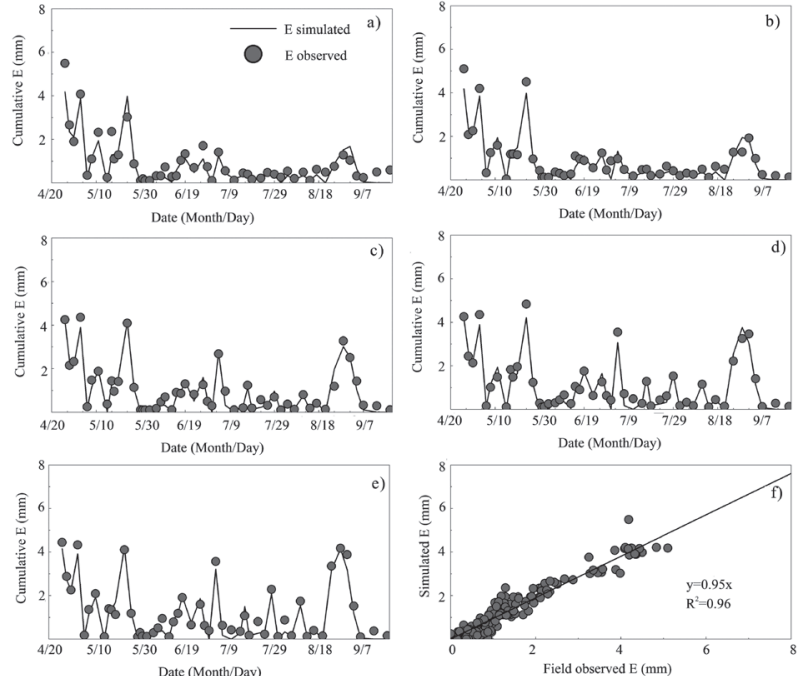

Fig. 5. Comparison between field-measured and model-simulated cumulative soil evaporation $(E)$ under treatments T1a), T2b), T3c), T4d), and T5e) in 2011 (validation).

by the termination of irrigation coupled with low temperatures in the study area. In agreement with Howell et al. [39], $K_{c \text { end }}$ dramatically dropped to within 0.1-0.2 during this period.

\section{Daily and Seasonal Evapotranspiration}

As a critical component of the hydrologic cycle, the simulated daily and seasonal $E T$ in cotton fields in north
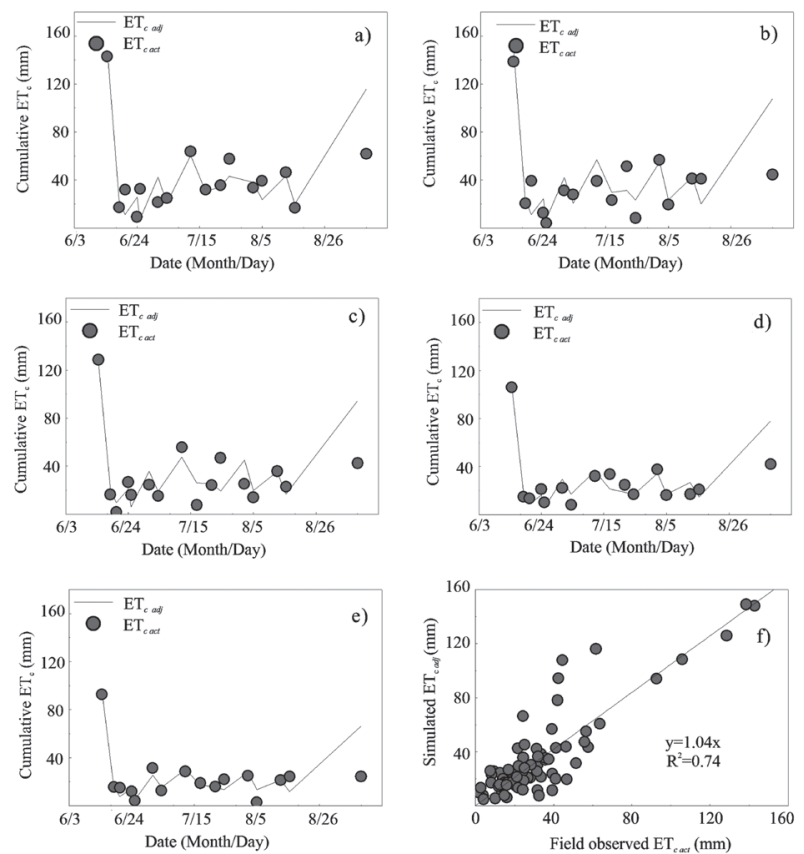

Fig. 6. Comparison between field-measured and modelsimulated cumulative crop evapotranspiration ( $E T_{c}$ and $E T_{c \text { adj }}$ ) under treatments $\mathrm{T} 1 \mathrm{a}$ ), T2 b), T3 c), T4 d), and T5 e) in 2011 (validation).

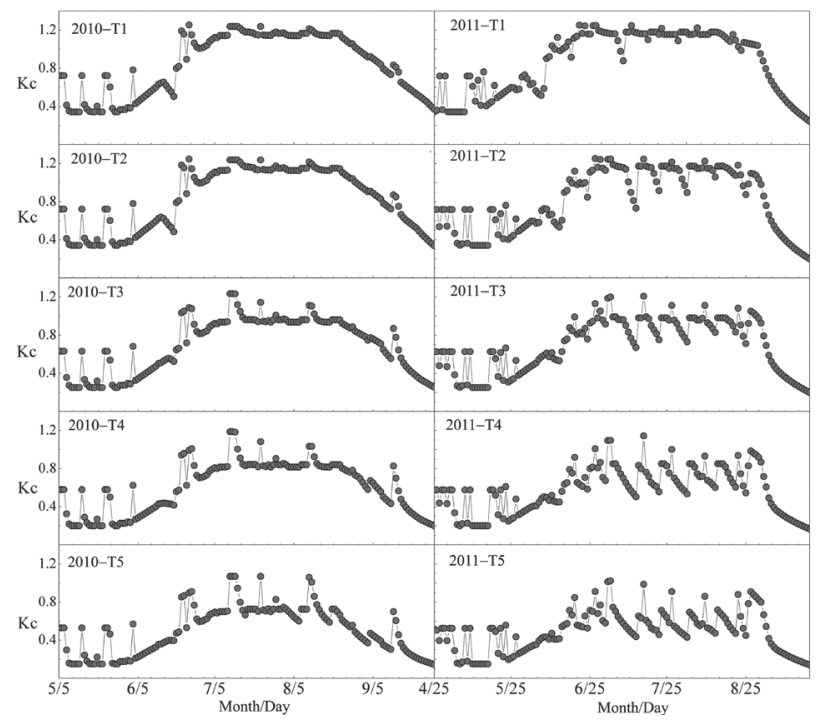

Fig. 7. Plots of the estimated daily dual crop coefficients $\left(K_{c}=K_{s} K_{c b}+K_{e}\right)$ of cotton under different irrigation treatments in 2010 and 2011.

Xinjiang are plotted in Fig. 8 and summarized in Table 5. The differences in daily $E T_{c}$ among the treatments were minimal at the start of the cotton growth season due to similar climatic and agronomic conditions. However, the differences started to increase after the implementation of different irrigation treatments. The maximum variations in $E T_{c}$ occurred during the period from early July to late August, due mainly to 2 reasons. The first was the difference in soil water content under each irrigation treatment, where high soil moisture resulted in high $E T_{c}$ [44]. The second was the difference in plant soil water uptake [37]. Both of these factors suggested that the soil water content was a major limiting element of $E T$ and

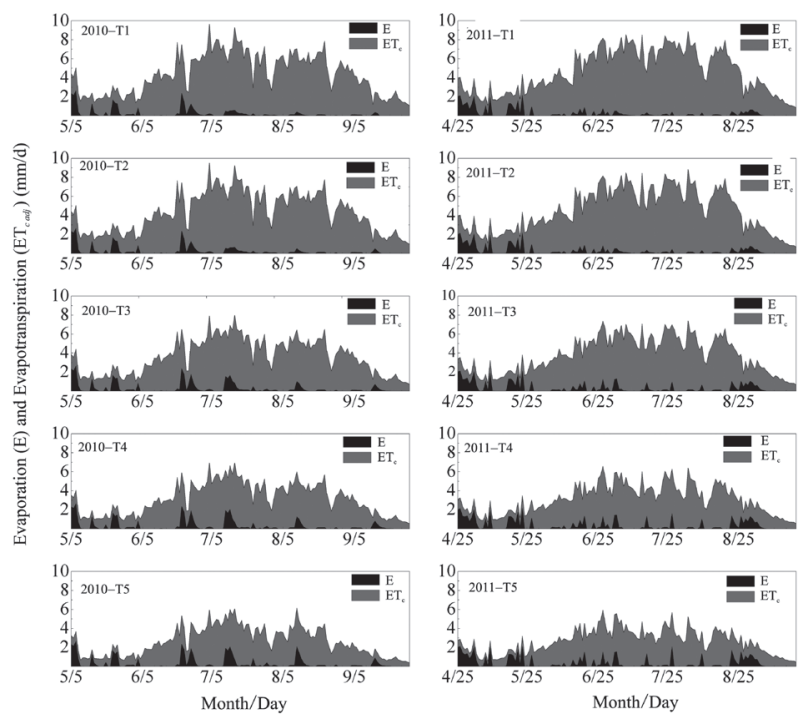

Fig. 8. Plots of daily estimated cotton evapotranspiration $\left(E T_{\text {cadj }}\right)$, soil evaporation $(E)$, and plant transpiration $\left(T=E T_{c a d j}{ }^{-} E\right)$ under different treatments in 2010 and 2011. 
Table 5. Average daily evapotranspiration $\left(E T_{c \text { adj }}\right)$ for the month of May through September, seasonal total of average daily evapotranspiration $\left(S T-E T_{c a d j}\right)$, ratio of evaporation to evapotranspiration $\left(E / E T_{c}\right)$, and ratio of transpiration to evapotranspiration $\left(T / E T_{c}\right)$ for cotton fields in the 2010 and 2011 experimental periods.

\begin{tabular}{|c|c|c|c|c|c|c|c|c|c|}
\hline \multirow{2}{*}{\multicolumn{2}{|c|}{ Treatment }} & \multicolumn{5}{|c|}{ Average daily $E T_{c}\left(\mathrm{~mm} \mathrm{~d}^{-1}\right)$} & \multirow{3}{*}{$\frac{S T-E T_{\text {cadj }}(\mathrm{mm})}{652}$} & \multirow{3}{*}{$\begin{array}{l}E / E T_{c} \\
5.7 \%\end{array}$} & \multirow{3}{*}{$\begin{array}{l}T / E T_{c} \\
94.3 \%\end{array}$} \\
\hline & & \multirow{2}{*}{$\begin{array}{l}\text { May } \\
2.36\end{array}$} & \multirow{2}{*}{$\begin{array}{l}\text { June } \\
4.26\end{array}$} & \multirow{2}{*}{$\begin{array}{l}\text { July } \\
6.57\end{array}$} & \multirow{2}{*}{$\begin{array}{c}\text { August } \\
5.74\end{array}$} & \multirow{2}{*}{$\begin{array}{c}\text { September } \\
2.71\end{array}$} & & & \\
\hline \multirow{5}{*}{2010} & $\mathrm{~T} 1$ & & & & & & & & \\
\hline & $\mathrm{T} 2$ & 2.36 & 4.20 & 6.50 & 5.67 & 2.66 & 644 & $5.8 \%$ & $94.2 \%$ \\
\hline & $\mathrm{T} 3$ & 1.89 & 3.56 & 5.54 & 4.77 & 2.17 & 541 & $7.9 \%$ & $92.1 \%$ \\
\hline & $\mathrm{T} 4$ & 1.63 & 3.05 & 4.91 & 4.20 & 1.77 & 469 & $9.2 \%$ & $90.8 \%$ \\
\hline & T5 & 1.36 & 2.63 & 4.26 & 3.43 & 1.26 & 390 & $11.0 \%$ & $89.0 \%$ \\
\hline \multirow{5}{*}{2011} & $\mathrm{~T} 1$ & 2.48 & 5.25 & 7.10 & 5.56 & 2.17 & 689 & $7.9 \%$ & $92.1 \%$ \\
\hline & $\mathrm{T} 2$ & 2.48 & 5.23 & 6.82 & 5.50 & 1.80 & 668 & $8.1 \%$ & $91.9 \%$ \\
\hline & $\mathrm{T} 3$ & 2.00 & 4.51 & 5.73 & 4.63 & 1.64 & 566 & $10.5 \%$ & $89.5 \%$ \\
\hline & $\mathrm{T} 4$ & 1.73 & 3.77 & 4.56 & 3.75 & 1.37 & 465 & $12.5 \%$ & $87.5 \%$ \\
\hline & T5 & 1.47 & 3.33 & 3.78 & 3.08 & 1.17 & 393 & $14.6 \%$ & $85.4 \%$ \\
\hline
\end{tabular}

that the variations in $E T_{c}$ (in July and August) were consistent with the changes in soil water deficit conditions. In the final growth stage, the differences in daily $E T_{c}$ among the treatments dramatically decreased due to near-cessation of transpiration and evaporation.

Similar to daily $E T_{c}$, average daily $E T_{c}$ varied from month to month under different soil water conditions (Table 5). For instance, in the T3 treatment, the average daily $E T_{c}$ was $1.89 \mathrm{~mm} \mathrm{~d}^{-1}$ in May 2010, increasing to $3.56 \mathrm{~mm} \mathrm{~d}^{-1}$ in June and reaching the maximum of $5.54 \mathrm{~mm} \mathrm{~d}^{-1}$ in July. It then decreased to $4.77 \mathrm{~mm} \mathrm{~d}^{-1}$ in August and dropped further to $2.17 \mathrm{~mm} \mathrm{~d}^{-1}$ in September. This trend was similar to that noted by Zhou et al. in 2012 [30], with some $350 \mathrm{~mm}$ of irrigation in 2009 but higher values in July (4.3-4.7 $\mathrm{mm} \mathrm{d}^{-1}$ ) and August (3.4-3.8 $\left.\mathrm{mm} \mathrm{d}^{-1}\right)$. For all the treatments in 2010 and 2011, the range of average daily $E T_{c}$ was $1.36-2.48 \mathrm{~mm} \mathrm{~d}^{-1}$ for May, 2.63-5.25 $\mathrm{mm} \mathrm{d}^{-1}$ for June, 3.78-7.10 $\mathrm{mm} \mathrm{d}^{-1}$ for July, 3.08-5.74 $\mathrm{mm} \mathrm{d}^{-1}$ for August, and 1.17-2.71 for September. This suggested that the higher the irrigation, the higher the average daily $E T_{\text {c }}$.

The total annual $E T$ for the cotton growth season decreased with decreasing irrigation. For the T1 and T2 treatments, total annual $E T_{c}$ was $652 \mathrm{~mm}$ and $644 \mathrm{~mm}$, respectively (2010), and 689 and $668 \mathrm{~mm}$, respectively (2011). This showed that deep percolation occurred under the T1 treatment. Liu et al. [35] also came to a similar conclusion based on an experiment in north Xinjiang and reported that the total annual $E T_{c}$ in cotton fields was approximately $600-700 \mathrm{~mm}$ under $60-80 \%$ of field water capacity. For the T3 treatment, the total annual $E T$ in 2010 and 2011 was $541 \mathrm{~mm}$ and $566 \mathrm{~mm}$, respectively. This is in good agreement with the findings of $\mathrm{Mu}$ et al. [45], Liu et al. [35], and Zhou et al. [30], where some $350 \mathrm{~mm}$ of irrigation in cotton fields resulted in 500-600 mm of total annual $E T_{c}$.

\section{Evaporation and Transpiration}

The $E T_{c}$ in the cotton fields was partitioned into its components of soil evaporation and crop transpiration using the soil water balance method in Equation (3). The dynamic variations in evaporation and transpiration under the different irrigation schedules were critical for efficient irrigation management in the region (Fig. 8).

Transpiration accounted for most of $E T$ in the study area. The ratios of evaporation to $E T_{c}(E / E T)$ and of transpiration to $E T_{c}(T / E T)$ for the experimental periods of 2010 and 2011 are given in Table 5. Transpiration accounted for $94.3 \%, 94.2 \%, 92.1 \%, 90.8 \%$, and $89 \%$ of total $E T$ in 2010 , and for $92.1 \%, 91.9 \%, 89.5 \%, 87.5 \%$, and $85.4 \%$ of total $E T$ in 2011 under irrigation treatments of $\mathrm{T} 1, \mathrm{~T} 2, \mathrm{~T} 3, \mathrm{~T} 4$, and $\mathrm{T} 5$, respectively. Evaporation accounted for only $5.7-11 \%$ of total $E T_{c}$ in 2010 and only $7.9-14.6 \%$ of total ET in 2011 under the different irrigation treatments. This was consistent with the results of $\mathrm{Li}$ et al. in 2013 [37], who found that evaporation accounted for some $6.3 \%$ of total $E T_{c}$ in maize fields under plastic mulch in an arid region in China. In all the treatments, evaporation occurred mainly during the initial growth stage $(0-25 \mathrm{~d})$ due to incomplete cover. Evaporation also occurred during the final growth stage due to leaf abscission after termination of irrigation.

Several studies have shown that soil evaporation is mainly affected by leaf cover and surface soil moisture conditions $[35,37]$. Contrary to the observations in this study, Liu et al. [35] noted that soil evaporation decreased with decreasing topsoil moisture content. This conclusion was based on a 5a (1995-2000) experiment study using micro-lysimeters to investigate soil evaporation in irrigated winter wheat and maize at the Luancheng Experimental Station on the North China Plain. As opposed to full irrigation, soil evaporation increased under deficit irrigation, due mainly to poor canopy 
conditions. Liu et al. [35] and $\mathrm{Li}$ et al. [37] also noted that the plant canopy significantly influenced soil water loss and that soil evaporation increased with decreasing LAI. Therefore, limiting evaporative water loss requires strategies that increase LAI during the early growth stages or that increase plastic mulch cover under deficit irrigation conditions [37, 45].

The FAO-56 dual crop coefficient approach is the method most widely used to estimate $E T_{c}$ and its components. In this study, micro-lysimeters were used (also a common field instrument) to measure $E T_{c}$ via the soil water balance method. However, the one year of validation data somehow limited conclusive results due to complex interactions among the atmosphere, soil, and plants. To overcome these limitations, several years of validation data are needed for a range of variables in the SIMDualKc model. Regardless, the results of this study contribute immensely to the understanding of the processes of $E T$ and its components, and this understanding is critical for water resource management, food security, and social stability.

\section{Conclusions}

Partitioning $E T_{c}$ into its constituent components increases our understanding of improving water use efficiency in agricultural production. With adequate knowledge of when, where, and how much water is lost, agricultural and other water management strategies can be optimized for maximum sustainable outputs. This study, which was an attempt to further this knowledge, used the SIMDualKc model to precisely estimate $E T_{c}$ and its components in cotton fields under full/deficit irrigation conditions in arid northwestern China.

The model results showed that the seasonal ET decreased with decreasing irrigation. Transpiration accounted for the majority of $E T_{c}$ (85.4-94.3\%), and evaporation accounted for only a small percentage of the ET (5.7-14.6\%) in the study area. Due to low $L A I$ conditions, the soil evaporation increased with increasing deficit irrigation. This suggested that evaporative water loss reduction strategies should focus on increasing $L A I$ - especially in the early growth stage. Evaporative water loss can also be reduced by increasing the fraction of the crop field under plastic mulch and by increasing the degree of water deficit irrigation.

However, the results of this study were limited by the limited data (one year of calibration data and one year of validation data) for the SIMDualKc model. Regardless, the results of the study have signification implications for water resource management, crop production/food security, and social stability in arid/semiarid regions around the globe.

\section{Acknowledgements}

This study was funded by the Natural Science Foundation of China (grant Nos. 41130641, 41390461, and 41371115).

\section{Conflict of Interest}

The authors declare no conflict of interest.

\section{References}

1. WANG Z., JIN M., ŠIMŮNEK J.,VAN GENUCHTEN M. T. Evaluation of mulched drip irrigation for cotton in arid Northwest China. Irrigation Science, 32 (1), 15, 2014.

2. ZHUO L., MEKONNEN, M. M., HOEKSTRA A. Y. The effect of inter-annual variability of consumption, production, trade and climate on crop-related green and blue water footprints and inter-regional virtual water trade: A study for China (1978-2008). Water research, 94, 73, 2016.

3. MOIWO J.P., TAO F. Contributions of precipitation, irrigation and soil water to evapotranspiration in (semi)arid regions. International Journal of Climatology, 35 (6), 1079, 2015

4. FERERES E., SORIANO M.A. Deficit irrigation for reducing agricultural water use. Journal of experimental botany, 58 (2), 147, 2006.

5. PEREIRA L.S., OWEIS T., ZAIRI A. Irrigation management under water scarcity. Agricultural water management, $\mathbf{5 7}$ (3), 175, 2002.

6. LI S., KANG S., LI F., ZHANG L. Evapotranspiration and crop coefficient of spring maize with plastic mulch using eddy covariance in northwest China. Agricultural Water Management, 95 (11), 1214, 2008.

7. ALLEN R.G., PEREIRA L.S., RAES D., SMITH M. Crop evapotranspiration-Guidelines for computing crop water requirements-FAO Irrigation and drainage paper 56. FAO, Rome, 300 (9), D05109, 1998.

8. PEREIRA L.S., PAREDES P., CHOLPANKULOV E. D., INCHENKOVA O.P., TEODORO P.R., HORST M.G. Irrigation scheduling strategies for cotton to cope with water scarcity in the Fergana Valley, Central Asia. Agricultural Water Management, 96 (5), 723, 2009.

9. FANDIÑO M., OLMEDO J.L., MARTÍNEZ E.M., VALLADARES J., PAREDES P., REY B.J., PEREIRA L.S. Assessing and modelling water use and the partition of evapotranspiration of irrigated hop (Humulus Lupulus), and relations of transpiration with hops yield and alphaacids. Industrial Crops and Products, 77, 204, 2015.

10. ALLEN R.G., PEREIRA L.S., HOWELL T.A., JENSEN M.E. Agricultural Water Management, 98 (6), 921, 2011.

11. ALLEN R.G., PEREIRA L.S., HOWELL T.A., JENSEN M.E. Evapotranspiration information reporting: I. Factors governing measurement accuracy. Agricultural Water Management, 98 (6), 899, 2011.

12. LÓPEZ-URREA R., MONTORO A., MAÑAS F., LÓPEZ-FUSTER P., FERERES, E. Evapotranspiration 
and crop coefficients from lysimeter measurements of mature 'Tempranillo'wine grapes. Agricultural water management, 112, 13, 2012.

13. LOVELLI S., PIZZA S., CAPONIO T., RIVELLI A., PERNIOLA M. Lysimetric determination of muskmelon crop coefficients cultivated under plastic mulches. Agricultural Water Management, 72 (2), 147, 2005.

14. GAVILÁN P., BERENGENA J. Accuracy of the Bowen ratio-energy balance method for measuring latent heat flux in a semiarid advective environment. Irrigation Science, 25 (2), 127, 2007.

15. INMAN-BAMBER N., MCGLINCHEY M. Crop coefficients and water-use estimates for sugarcane based on long-term Bowen ratio energy balance measurements. Field Crops Research, 83 (2), 125, 2003.

16. ZHANG B., KANG S., LI F., ZHANG L. Comparison of three evapotranspiration models to Bowen ratio-energy balance method for a vineyard in an arid desert region of northwest China. Agricultural and Forest Meteorology, 148 (10), 1629, 2008

17. POBLETE-ECHEVERRÍA C., SEPÚLVEDA-REYES D., ZÚÑIGA M., ORTEGA-FARÍAS S. Grapevine crop coefficient $(\mathrm{Kc})$ determined by surface renewal method at different phenological periods. In VIII International Symposium on Irrigation of Horticultural Crops, 1150, 6166, 2015.

18. RAJAN N., MAAS S.J., KATHILANKAL J.C. Estimating crop water use of cotton in the Texas High Plains. Agronomy journal, 102 (6), 1641, 2010.

19. DEJONGE K.C., ASCOUGH J.C., ANDALES A.A., HANSEN N.C., GARCIA L.A., ARABI M. Improving evapotranspiration simulations in the CERES-Maize model under limited irrigation. Agricultural Water Management, 115, 92, 2012.

20. ROSA R.D., PAREDES P., RODRIGUES G.C., ALVES I., FERNANDO R.M., PEREIRA L.S., ALLEN R.G. Implementing the dual crop coefficient approach in interactive software. 1. Background and computational strategy. Agricultural Water Management, 103, 8, 2012.

21. ROSA R.D., PAREDES P., RODRIGUES G.C., FERNANDO R.M., ALVES I., PEREIRA L.S., ALLEN R.G. Implementing the dual crop coefficient approach in interactive software: 2. Model testing. Agricultural Water Management, 103, 62, 2012.

22. TIAN F., YANG P., HU H., DAI C. Partitioning of cotton field evapotranspiration under mulched drip irrigation based on a dual crop coefficient model. Water, 8 (3), 72, 2016.

23. GHAMARNIA H., AMIRKHANI D., ARJI I. Basil (Ocimum basilicum L.) Water Use, Crop Coefficients and SIMDualKc Model Implementing in a Semi-arid Climate. International Journal of Plant \& Soil Science, 4 (6), 535, 2015.

24. REN D., XU X., HAO Y., HUANG G. Modeling and assessing field irrigation water use in a canal system of Hetao, upper Yellow River basin: Application to maize, sunflower and watermelon. Journal of Hydrology, 532, 122, 2016.

25. RODRIGUES G.C., PAREDES P., GONÇALVES J.M., ALVES I., PEREIRA L.S. Comparing sprinkler and drip irrigation systems for full and deficit irrigated maize using multicriteria analysis and simulation modelling: Ranking for water saving vs. farm economic returns. Agricultural water management, 126, 85, 2013.
26. MARTINS J.D., RODRIGUES G.C., PAREDES P., CARLESSO R., OLIVEIRA Z.B., KNIES A.E., PEREIRA L.S. Dual crop coefficients for maize in southern Brazil: Model testing for sprinkler and drip irrigation and mulched soil. Biosystems engineering, 115 (3), 291, 2013.

27. PAREDES P., RODRIGUES G., ALVES I., PEREIRA, L. Partitioning evapotranspiration, yield prediction and economic returns of maize under various irrigation management strategies. Agricultural water management, 135, 27, 2014.

28. ZHANG B., LIU Y., XU D., ZHAO N., LEI B., ROSA R. D., PEREIRA L.S. The dual crop coefficient approach to estimate and partitioning evapotranspiration of the winter wheat-summer maize crop sequence in North China Plain. Irrigation Science, 31(6), 1303, 2013.

29. ZHAO N., LIU Y., CAI J., PAREDES P., ROSA R.D. PEREIRA L.S. Dual crop coefficient modelling applied to the winter wheat-summer maize crop sequence in North China Plain: Basal crop coefficients and soil evaporation component. Agricultural water management, 117, 93, 2013.

30. ZHOU S., WANG J., LIU J., YANG J., XU Y., LI J. Evapotranspiration of a drip-irrigated, film-mulched cotton field in northern Xinjiang, China. Hydrological Processes, 26 (8), 1169, 2012.

31. WANG R., WAN S., KANG Y., DOU C. Assessment of secondary soil salinity prevention and economic benefit under different drip line placement and irrigation regime in northwest China. Agricultural water management, 131, 41, 2014.

32. ZHENG C., KANG Y., YAO S., YAN C., SUN Z. Method of root analysis using GIS technology. Transactions of the Chinese Society of Agricultural Engineering, 20 (1), 181, 2004.

33. LI D.W., LI M.S., SHEN X.J., YANG L., ZHOU Y., LIU D. Effect of Moisture and Heat Coupling in Soil Wetting Pattern on the Cotton Growth under Mulched Drip Irrigation. Journal of Irrigation and Drainage, 5, 11, 2011.

34. OWEIS T., FARAHANI H., HACHUM A. Evapotranspiration and water use of full and deficit irrigated cotton in the Mediterranean environment in northern Syria. Agricultural water management, 98 (8), 1239, 2011

35. LIU C., ZHANG X., ZHANG Y. Determination of daily evaporation and evapotranspiration of winter wheat and maize by large-scale weighing lysimeter and microlysimeter. Agricultural and Forest Meteorology, 111 (2), 109, 2002.

36. ALLEN R.G. Using the FAO-56 dual crop coefficient method over an irrigated region as part of an evapotranspiration intercomparison study. Journal of Hydrology, 229 (1), 27, 2000.

37. LI S., WANG Z., LI S., GAO Y., TIAN X. Effect of plastic sheet mulch, wheat straw mulch, and maize growth on water loss by evaporation in dryland areas of China. Agricultural water management, 116, 39, 2013.

38. GARCÍA-VILA M., FERERES E., MATEOS L., ORGAZ F., STEDUTO P. Deficit irrigation optimization of cotton with AquaCrop. Agronomy journal, 101 (3), 477, 2009.

39. HOWELL T., EVETT S., TOLK J., SCHNEIDER A. Evapotranspiration of full-, deficit-irrigated, and dryland cotton on the Northern Texas High Plains. Journal of irrigation and drainage engineering, 130 (4), 277, 2004.

40. HUNSAKER D.J., PINTER P.J., BARNES E.M., KIMBALL B.A. Estimating cotton evapotranspiration 
crop coefficients with a multispectral vegetation index. Irrigation Science, 22 (2), 95, 2003.

41. FARAHANI H., OWEIS T., IZZI G. Crop coefficient for drip-irrigated cotton in a Mediterranean environment. Irrigation science, 26 (5), 375, 2008.

42. KO J., PICCINNI G., MAREK T., HOWELL T. Determination of growth-stage-specific crop coefficients (Kc) of cotton and wheat. Agricultural Water Management, 96 (12), 1691, 2009.

43. SULEIMAN A.A., SOLER C.M.T., HOOGENBOOM G. Evaluation of FAO-56 crop coefficient procedures for deficit irrigation management of cotton in a humid climate. Agricultural water management, 91 (1), 33, 2007.

44. JORDAN W.R., RITCHIE J.T. Influence of soil water stress on evaporation, root absorption, and internal water status of cotton. Plant physiology, 48 (6), 783, 1971.

45. MU C., MA F., ZHENG X., ZHENG Z., LI F., CHENG $H$. Simulation of evapotranspiration under the condition of drip irrigation with plastic film mulching in cotton field. Transactions of the Chinese Society of Agricultural Engineering, 21 (4), 25, 2005. 
